\title{
Laparoscopic treatment of patients with colorectal cancer - Technique assessment at an oncological centre
}

\author{
Przemysław Ciepiela', Paweł Macek ${ }^{2,3}$, Jacek Haduch', Stanisław Góźdźz,5 \\ ${ }^{1}$ Clinic of Oncological Surgery, Holycross Cancer Center, Kielce, Poland \\ ${ }^{2}$ Department of Epidemiology and Cancer Control, Holycross Cancer Center, Kielce, Poland \\ ${ }^{3}$ Faculty of Medical Sciences, University of Economics, Law and Medical Sciences prof. Edward Lipinski, Kielce, Poland \\ ${ }^{4}$ Clinic of Clinical Oncology, Holycross Cancer Center, Kielce, Poland \\ ${ }^{5}$ Faculty of Medicine and Health Sciences, Jan Kochanowski University, Kielce, Poland
}

Ciepiela P, Macek P, Haduch J, Góźdź S. Laparoscopic treatment of patients with colorectal cancer - the technique's assessment at an oncological centre. Med. Og Nauk Zdr. 2019; 25(1): 22-26. doi: 10.26444/monz/105259

\section{Abstract}

Introduction and objective. Colorectal cancer is the third most common cancer in males and the second in females in the Świętokrzyskie region of southeast Poland. In 2015, 354 new colorectal cancer cases in males and 290 in females were reported. Minimally invasive procedures with a modern approach to preoperative care have become a new challenge for the surgeon and a link to robotic surgery. The aim of the study is to analysis surgical complications in the first years from the introduction of laparoscopic procedures for colorectal cancer surgery.

Materials and method. Laparoscopic colon resection started at the Department of Surgical Oncology of the Świętokrzyskie Cancer Centre in 2011. The method was applied in the treatment of 196 patients mainly with malignant tumour of the colon and the rectum. In $30.6 \%$ of patients, open conversion to the procedure was performed. Complications and long-term results were analysed, assessing the operating time, length of hospital stay, local complications as well as early and late mortality. Results. The duration of laparoscopic procedures was longer compared to the treatment through laparotomy. The median of hospital stay was seven days. The following complications were observed: infection of the surgical wound in $4.1 \%$ patients, bleeding or wound dehiscence and hernia anastomosis in $2.4 \%$ patients. The conversion was performed in 58 patients, most often because of adhesions (42\%) or extensive infiltration of tumour (39\%). Early postoperative mortality of up to 30 days after the surgery was observed in $0.5 \%$ patient, while within a year after surgery - in $8.2 \%$ of patients.

Conclusions. In the course of laparoscopic colon resection, no increase was observed in the number of perioperative complications. A large percentage of conversion demonstrates the need for further training of the operating team.

\section{Key words}

laparoscopic surgery, laparoscopy, colorectal cancer, complications

\section{INTRODUCTION}

The development of new technologies and a better understanding of the pathophysiology modify the methods of treatments and assist physicians in the selection of procedures. However, they are also a technical challenge for surgeons who need to learn new and frequently complex procedures [1].

Classical surgery is slowly being supplanted by laparoscopic and robotic surgery. Treatment results obtained by means of modern techniques are now comparable to "open" surgery $[2,3]$. It seems that in future the contemporary methods will become the standard procedure. For this reason, in 2011, laparoscopic techniques in the surgical treatment of cancer of the colon and the rectum were introduced in the Oncological Surgery Clinic of the Holycross Cancer Centre in Kielce. The study presents and analyses the results of material from the first seven years of applying laparoscopic surgery at the Clinic. It also aimed to identify surgical complications in the first years from the introduction of laparoscopic procedures for colorectal cancer surgery.

Address for correspondence: Paweł Macek, Department of Epidemiology and Fighting Cancer, Świętokrzyskie Centrum Onkologii, Kielce, Artwińskiego 3, 25-734, Kielce, Poland

E-mail: pawel.macek@gazeta.pl

Received: 11 February 2019; Accepted: 4 March 2019

\section{MATERIALS AND METHOD}

Between 2011-2017 in the Oncological Surgery Clinic laparoscopic procedures were performed in 196 patients, and in 57 patients $(29 \%)$ the procedure was completed by laparotomy. At that time, there were four surgeons performing operations and the maximum number of procedures performed by one of them was 113. Patients were not selected for laparoscopic treatment; it was carried out after mechanical preparation of the intestine, supported by anticoagulants and antibiotics. Small tumours in the intestine were determined in the preoperative colonoscopy by injecting ink. In the period under analysis, 101 males and 95 females were operated on. The average age of patients was 62.8 years, while the oldest patient operated on was 91-years-old.

A history of internal diseases and co-morbidities was scored using the Charlson Comorbidity Index (CCI) and additionally Age-Adjusted Charlson Comorbidity Index (CCI-age). The mean score of the mentioned indexes was 3.2 and 5.2, respectively (maximum 11 points). In the analysed group of patients, two were diagnosed with neuroendocrine tumours, 12 were operated on due to advanced adenomas, whereas the remaining 182 patients were diagnosed with adenocarcinoma of the colon and rectum.

Among patients undergoing laparoscopic treatment only (i.e. without conversion to laparotomy) the largest group 
Table 1. Basic characteristics of study group

\begin{tabular}{|c|c|}
\hline Variable & $\mathrm{n}=196$ \\
\hline Age (years) & $62.8 \pm 12.3$ \\
\hline \multicolumn{2}{|l|}{ Gender, $\mathrm{n}(\%)$} \\
\hline Male & $101(51.5)$ \\
\hline Female & $95(48.5)$ \\
\hline \multicolumn{2}{|l|}{ Type of surgery, n (\%) } \\
\hline Lapatoscopy & $136(69.4)$ \\
\hline Laparotomy & $60(30.6)$ \\
\hline $\mathrm{CCl}$ (points) & $3.2 \pm 1.4$ \\
\hline CCl-age (points) & $5.2 \pm 2.0$ \\
\hline \multicolumn{2}{|l|}{ T-stage, n (\%) } \\
\hline cT1 & $22(11.2)$ \\
\hline cT2 & $47(24)$ \\
\hline сT3 & $103(52.6)$ \\
\hline CT4 & $17(8.7)$ \\
\hline Missing values, $\mathrm{n}(\%)$ & $7(3.6)$ \\
\hline \multicolumn{2}{|l|}{ N-stage, n (\%) } \\
\hline cNO & $122(62.2)$ \\
\hline $\mathrm{cN} 1$ & $64(32.7)$ \\
\hline $\mathrm{cN} 2$ & $3(1.5)$ \\
\hline Missing values, $\mathrm{n}(\%)$ & $7(3.6)$ \\
\hline \multicolumn{2}{|l|}{ UICC stage, n (\%) } \\
\hline 1 & $64(32.7)$ \\
\hline ॥ & $58(29.6)$ \\
\hline III & $60(30.6)$ \\
\hline IV & $7(3.6)$ \\
\hline Missing values, n (\%) & $7(3.6)$ \\
\hline \multicolumn{2}{|l|}{ Chemotherapy, n (\%) } \\
\hline Yes & $7(3.6)$ \\
\hline No & $189(96.4)$ \\
\hline \multicolumn{2}{|l|}{ Radiation therapy, n (\%) } \\
\hline Yes & $7(3.6)$ \\
\hline No & $189(96.4)$ \\
\hline \multicolumn{2}{|l|}{ Hormone therapy, $\mathrm{n}(\%)$} \\
\hline Yes & $3(1.5)$ \\
\hline No & $193(98.5)$ \\
\hline \multicolumn{2}{|l|}{ Conversions, n (\%) } \\
\hline Yes & $58(29.6)$ \\
\hline No & $138(70.4)$ \\
\hline Time of hospitalization (days) & $7.8(4.9)$ \\
\hline Follow-up (days) & $902.1 \pm 655.5$ \\
\hline
\end{tabular}

comprised patients in the first clinical stage, according to the TNM classification (48 patients $-24.4 \%$ ). In the group of patients who underwent laparotomy, tumour classified as the III stage of clinical advancement was reported in 23 patients $(11.8 \%)$. In the analysed material, nine patients had been treated previoudsly for other malignancies.

\section{RESULTS}

The most frequent procedure in the analysed group of patients was laparoscopic resection of the rectum, performed in 65 (33.2\%) patients. The next most common procedure involved laparoscopic right-sided haemicolectomy, performed in 39 (19.9\%) patients, and sigmoid resection performed in 32 (16.3\%) patients.

Conversion to laparotomy was performed in 58 (29.6\%) patients. The most common reason for performing laparotomy included adhesions from previous surgery (42\%) and extensive tumour invasion (39\%). The most frequent procedure performed after conversion was right-sided haemicolectomy, carried out in 24 (12.2\%) patients, followed by anterior resection of the rectum - 17 (8.7\%) treatments. During the 11 (5.6\%), laparoscopic procedures and 13 (6.6\%) procedures after conversion other procedures, such as cholecystectomy, cystic ovarian resection, appendectomy, or resection of a liver tumour, were performed. 17 (8.7\%) patients received neoadjuvant treatment: preoperative radiotherapy in seven (3.5\%) patients, exclusive systemic treatment in seven $(3.5 \%)$ patients and combined chemoradiation in three (1.5\%) patients. Tables 2 and 3 present the demographic and clinical characteristics of patients who

Table 2. Demographical and clinical characteristics of patients in the laparoscopy group (without conversion)

\begin{tabular}{|c|c|c|c|}
\hline Variable & $\begin{array}{l}\text { Right } \\
\text { haemicolectomy }\end{array}$ & $\begin{array}{l}\text { Sigmoid } \\
\text { resection }\end{array}$ & $\begin{array}{l}\text { Rectal } \\
\text { resection }\end{array}$ \\
\hline All, n (\%) & $39(19.9)$ & $32(16.3)$ & $65(33.2)$ \\
\hline \multicolumn{4}{|l|}{ Gender, n (\%) } \\
\hline Female & $22(11.2)$ & $14(7.1)$ & $27(13.8)$ \\
\hline Male & $17(8.7)$ & $18(9.2)$ & $38(19.4)$ \\
\hline \multicolumn{4}{|l|}{ Age, n (\%) } \\
\hline $00-49$ & $5(2.6)$ & $1(0.5)$ & $11(5.6)$ \\
\hline $50-59$ & $7(3.6)$ & $11(5.6)$ & $21(10.7)$ \\
\hline $60-69$ & $16(8.2)$ & $11(5.6)$ & $24(12.2)$ \\
\hline $70-79$ & $9(4.6)$ & $7(3.6)$ & $7(3.6)$ \\
\hline $80+$ & $2(1.0)$ & $2(1.0)$ & $2(1.0)$ \\
\hline \multicolumn{4}{|l|}{ T-stage, n (\%) } \\
\hline cT1 & $4(2)$ & $3(1.5)$ & $12(6.1)$ \\
\hline cT2 & $11(5.6)$ & $9(4.6)$ & $13(6.6)$ \\
\hline сT3 & $19(9.7)$ & $19(9.7)$ & $38(19.4)$ \\
\hline cT4 & $2(1.0)$ & $1(0.5)$ & $1(0.5)$ \\
\hline Missing values, n (\%) & $3(1.5)$ & no & $1(0.5)$ \\
\hline \multicolumn{4}{|l|}{$\mathrm{N}$-stage, n (\%) } \\
\hline cNO & $24(12.2)$ & $21(10.7)$ & $45(23)$ \\
\hline $\mathrm{cN} 1$ & $12(6.1)$ & $11(5.6)$ & $19(9.7)$ \\
\hline cN2 & no & no & no \\
\hline Missing values, n (\%) & $3(1.5)$ & no & $1(0.5)$ \\
\hline \multicolumn{4}{|l|}{ UICC stage, $\mathrm{n}(\%)$} \\
\hline 1 & $14(7.1)$ & $11(5.6)$ & $23(11.7)$ \\
\hline II & $10(5.1)$ & $10(5.1)$ & $22(11.2)$ \\
\hline III & $12(6.1)$ & $10(5.1)$ & $15(7.7)$ \\
\hline IV & no & $1(0.5)$ & $4(2.0)$ \\
\hline Missing values, n (\%) & $3(1.5)$ & no & $1(0.5)$ \\
\hline
\end{tabular}


Table 3. Demographical and clinical characteristics of patients in the laparoscopy with conversion group

\begin{tabular}{|c|c|c|c|c|}
\hline Variable & $\begin{array}{l}\text { Left } \\
\text { haemico- } \\
\text { lectomy }\end{array}$ & $\begin{array}{l}\text { Sigmoid } \\
\text { resection }\end{array}$ & $\begin{array}{l}\text { Rectal } \\
\text { resection }\end{array}$ & $\begin{array}{c}\text { Right } \\
\text { haemico- } \\
\text { lectomy }\end{array}$ \\
\hline All, $n(\%)$ & $6(3.1)$ & $13(6.6)$ & $17(8.7)$ & $24(12.2)$ \\
\hline \multicolumn{5}{|l|}{ Gender, n (\%) } \\
\hline Female & $4(2.0)$ & $7(3.6)$ & $7(3.6)$ & $14(7.1)$ \\
\hline Male & $2(1.0)$ & $6(3.1)$ & $10(5.1)$ & $10(5.1)$ \\
\hline \multicolumn{5}{|l|}{ Age, n (\%) } \\
\hline $00-49$ & no & $2(1.0)$ & $2(1.0)$ & $2(1.0)$ \\
\hline $50-59$ & no & $3(1.5)$ & $3(1.5)$ & $1(0.5)$ \\
\hline $60-69$ & no & $4(2)$ & $8(4.1)$ & $7(3.6)$ \\
\hline $70-79$ & $6(3.1)$ & $3(1.5)$ & $2(1.0)$ & $8(4.1)$ \\
\hline $80+$ & no & $1(0.5)$ & $2(1.0)$ & $6(3.1)$ \\
\hline \multicolumn{5}{|l|}{ T-stage, n (\%) } \\
\hline cT1 & no & $1(0.5)$ & $1(0.5)$ & $1(0.5)$ \\
\hline cT2 & $3(1.5)$ & $2(1.0)$ & $4(2.0)$ & $5(2.6)$ \\
\hline cT3 & $3(1.5)$ & $5(2.6)$ & $9(4.6)$ & $10(5.1)$ \\
\hline cT4 & no & $5(2.6)$ & $2(1.0)$ & $6(3.1)$ \\
\hline Missing values, $\mathrm{n}(\%)$ & no & no & $1(0.5)$ & $2(1.0)$ \\
\hline \multicolumn{5}{|l|}{ N-stage, n (\%) } \\
\hline cNO & $5(2.6)$ & $6(3.1)$ & $10(5.1)$ & $11(5.6)$ \\
\hline $\mathrm{cN} 1$ & $1(0.5)$ & $6(3.1)$ & $6(3.1)$ & $9(4.6)$ \\
\hline $\mathrm{cN} 2$ & no & $1(0.5)$ & no & $2(1.0)$ \\
\hline Missing values, $\mathrm{n}(\%)$ & no & no & $1(0.5)$ & $2(1.0)$ \\
\hline \multicolumn{5}{|l|}{ UICC stage, n (\%) } \\
\hline I & $3(1.5)$ & $3(1.5)$ & $5(2.6)$ & $5(2.6)$ \\
\hline ॥ & $2(1.0)$ & $3(1.5)$ & $5(2.6)$ & $6(3.1)$ \\
\hline III & $1(0.5)$ & $6(3.1)$ & $5(2.6)$ & $11(5.6)$ \\
\hline IV & no & $1(0.5)$ & $1(0.5)$ & no \\
\hline Missing values, $\mathrm{n}(\%)$ & no & no & $1(0.5)$ & $2(1.0)$ \\
\hline
\end{tabular}

no - not observed; T-stage - clinical stage of tumour; $\mathrm{N}$-stage - clinical stage of nodes

underwent successful laparoscopic treatment and patients who required conversion to open surgery.

The average time of laparoscopic procedure was, respectively: 3.2 hours for right-sided haemicolectomy, 3.1 hours for resection of the sigmoid, and 3.2 hours for resection of the rectum. Accordingly, the conversion of these treatments lasted an average of 2.8, 2.5 and 2.8 hours. Generally, the average treatment time was 3.1 hours (minimum 1.4 hours, maximum 11.1 hours).

In the analysed period of seven years of studying the laparoscopic method, 21 (10.7\%) patients reported complications during hospitalization: surgical site infection in eight $(4.1 \%)$ patients, bleeding in two (1\%) patients, eventeration in one $(0.5 \%)$ patient, hernia in troacar wound in one ( $0.5 \%)$ patient, anastomotic leakage in two patients (1\%), metabolic, cardiac and psychiatric complications in three (1.5\%) patients. Most of these complications were treated conservatively, three (1.5\%) patients underwent relaparotomy, one patient - re-laparoscopy, while one patient required endoscopic intervention. The average hospital stay was 7.8 days (ranging from 5-38 days). The longest stay was reported in a patient with anastomotic leakage, treated conservatively.

The total observation period after surgical treatment equalled, an average, 902 days (median 687 days of observation). Postoperative mortality (up to 30 days after surgery) was $0.5 \%$ (one death). 18 (9.2\%) patients died within a year of the operation. In the group in which the Charlson Comorbidity Index (CCI) was four points, two patients died within 90 days. Table 4 presents information about the complications and deaths reported in the study group (both for patients with conversion to laparotomy and for patients operated laparoscopically only).

Table 4. Complications and mortality

\begin{tabular}{lccc}
\hline Complications & Laparoscopy & Open surgery & All \\
\hline Wound infection, $\mathrm{n}(\%)$ & $1(0.5)$ & $7(3.6)$ & $8(4.1)$ \\
\hline Bleeding, $\mathrm{n}(\%)$ & $1(0.5)$ & $1(0.5)$ & $2(1.0)$ \\
\hline Eventeration, $\mathrm{n}(\%)$ & $\mathrm{no}$ & $1(0.5)$ & $1(0.5)$ \\
\hline Inciscional hernia, $\mathrm{n}(\%)$ & $1(0.5)$ & $\mathrm{no}$ & $1(0.5)$ \\
\hline Anastomotic leak, $\mathrm{n}(\%)$ & $\mathrm{no}$ & $2(1.0)$ & $2(1.0)$ \\
\hline Ureter demaged, $\mathrm{n}(\%)$ & $1(0.5)$ & $\mathrm{no}$ & $1(0.5)$ \\
\hline 30-days mortality, $\mathrm{n}(\%)$ & $\mathrm{no}$ & $1(0.5)$ & $1(0.5)$ \\
\hline 90-days mortality, $\mathrm{n}(\%)$ & $1(0.5)$ & $\mathrm{no}$ & $1(0.5)$ \\
\hline
\end{tabular}

no- not observed

\section{DISCUSSION}

Colorectal cancer is the third most common cancer in males and the second in females in the Świętokrzyskie region. In 2015, 197 incidents of colon cancer in males and 179 in females were reported, whereas 155 males and 104 females suffered from rectosigmoid junction and cancers of the rectum [4].

Since the introduction of laparoscopic cholecystectomy into surgical practice, there has been significant technological progress associated with the construction of cameras, image quality and improved methods of mechanical sewing. This has led to the common use of laparoscopy in colon resection.

The results of surgical treatment of colorectal cancer by the open approach and laparoscopy are similar, as confirmed by studies in large groups of patients. A good example would be the multi-centre European study COLOR, initiated in 1997, evaluating the efficacy of laparoscopy compared to the open procedure for colon cancer in terms of early complications and late treatment results [3]. The authors reported no difference between the two methods of procedure in terms of microscopic radicality of resection (both shoulders $98 \%$ ). Similar results were presented in a prospective multi-centre study LAPCOLON by Huscher et al., who evaluated the results of laparoscopic treatment of patients with colorectal cancer, operated on in 2001-2004 [5]. In 95\% of cases, procedure performed was microscopically radical. Five-year disease-free survival was observed in $86.7 \%$ of patients, whereas in the group of patients aged 50-79, laparoscopy was an independent factor significantly lowering mortality (OR 0.59; $\mathrm{p}<0.001$ ).

Similar conclusions were obtained in the multi-centre randomized COLOR II study conducted in 2004-2010 [6]. The authors demonstrated a comparable amount of radical resection, early mortality and number of perioperative complications in patients treated by laparoscopic and open methods. Early mortality in the evaluated patients was $1 \%$ in patients treated laparoscopically and $2 \%$ in a group operated 
on by the classical method. Similar results were achieved in patients treated in Kielce, recording $0.5 \%$ mortality within 30 days after surgery. A similar percentage of early mortality was demonstrated in an Italian study - 1.2\% [5] and a German study $-0.9 \%$ [7].

In the current study, the number of surgical complications after laparoscopic treatment was $10.7 \%$. Similar results are presented a Belgian prospective study evaluating treatment outcomes in 2009-2015 in patients who reported $17.9 \%$ complications [8], and by British researchers - 12.4\% [9]. In the group of older patients ( $>65$-years-old) the number of complications was greater, which is confirmed by Cummings et al., who reported the proportion of complications at $21.5 \%$ and early mortality at 3.3\% [10]. Similar worse results in the population of elderly people over 85 years of age are reported by Devoto et al. [11], who assessed the number of surgical complications at $23 \%$, which was associated with greater local severity of disease in these patients.

In the group of patients who underwent surgery in Kielce, surgical site infection after laparoscopy was reported in seven patients, representing $0.5 \%$ of the group. The results presented by other authors range from $0 \%$ (Cummings et al. [10]) to $12.1 \%$ (Fagard et al. [8]).

One of the factors examined in the course of studying laparoscopy, testifying to the training quality, is the percentage of conversion. With the development of technical skills and greater experience a decline in conversion to open surgery is observed [12]. In the COLOR study, the percentage of conversion was $17 \%$ [3], whereas in the LAPCOLON study - $10.5 \%$ [5]. In the material obtained from the Świętokrzyskie Cancer Centre the, average number of conversion was $30.6 \%$, which is most likely related to the learning curve. For the first six years, an increase in the percentage of conversion up to $40 \%$ was recorded, and in the following year, a reduction to $35 \%$ was observed. According to the literature data, the estimated number of laparoscopic surgeries which allows achievement in proficiency in the art of laparoscopy is a minimum of 55-62 resections of the colon [13], and over 60 resections of the rectum [14]. The average time of laparoscopic procedure in the authors' own material was longer than using open surgery, and equalled more than three hours (maximum 11 hours in a patient with iatrogenic damage to the ureter). Similar observations have also been reported by other researchers $[3,6]$. However, it is not associated with an increased rate of complications. The approach to patients who are on the learning curve of a surgeon is problematic. Hence, the desire to shorten the learning time because the initial treatments are associated with worse outcomes and higher rates of conversion [15]. On the other hand, laparoscopic treatments lead to better results in older patients burdened with chronic diseases [11]. After minimally invasive surgery, post-operative pain is less intense and there are reduced medical complications during hospitalization $[3,7]$.

Assessing elderly patients burdened with comorbidities, undergoing laparoscopic treatment at our Centre, it has been noted that this is a good method, resulting in tangible benefits, and the observations are consistent with the results of other authors. The DSCA study found that especially this group of patients with a serious history of internal diseases benefits from laparoscopic surgery [16].

Laparoscopic procedures applied in the treatment of colorectal cancer, in recent years have gained widespread acceptance and thus have consolidated their position thanks to numerous multi-centre studies, which confirmed the efficacy, safety, and oncological results of such procedures. These procedures have proved to be no worse than in the case of open surgery, and in the perioperative period are associated with fewer complications and a better quality of life.

Limitations of the study. The lack of assessment of the group of patients operated on by laparotomy for colorectal cancer during the described period means that the number of complications after laparoscopic procedures cannot be compared with the open procedures in the field of surgical site infection, bleeding or anastomotic leakage. For the same reason, mortality after both types of treatments cannot be assessed. A short period of observation does not allow for unambiguous assessment of oncological results of treatment. Laparoscopic experience regarding the operation of the team of four surgeons does not take into account the division into patients, whose surgical treatment fell on particular stages of the doctor $>$ learning curve. The presented results only show the authors' experience and cannot be the basis for drawing conclusions about the advantage of one of the methods of surgical treatment over the other.

\section{CONCLUSIONS}

The number of complications in the analysed period of seven years is comparable with reports from more experienced centres. The high number of conversion indicates the need for further training courses which will help to achieve satisfactory surgical and oncological results.

\section{REFERENCES}

1. Juo Y-Y, Hyder O, Haider AH, Camp M, Lidor A, A huja N. Is Minimally Invasive Colon Resection Better Than Traditional Approaches? First Comprehensive National Examination With Propensity Score Matching. JAMA Surg. 2014; 149(2): 177. https://doi.org/10.1001/ jamasurg.2013.3660.

2. Cheong C, Kim NK. Minimally Invasive Surgery for Rectal Cancer: Current Status and Future Perspectives. Indian J Surg Oncol. 2017; 8(4): 591-599. doi: 10.1007/s13193-017-0624-7.

3. Veldkamp R, Kuhry E, Hop WCJ, Jeekel J, Kazemier G, Bonjer HJ, et al. Laparoscopic surgery versus open surgery for colon cancer: short-term outcomes of a randomised trial. Lancet Oncol. 2005; 6(7): 477-484. doi:10.1016/S1470-2045(08)70310-3.

4. Giemza A, Smok-Kalwat J, Stępień D, Smorąg L, Macek P, Góźdź S. Nowotwory złośliwe w województwie Świętokrzyskim w 2015 roku. Świętokrzyskie Centrum Onkologii; 2017; //https://www.onkol.kielce. $\mathrm{pl} / \mathrm{pl} /$ centrum/zaklad-epidemiologii-i-walki-z-rakiem

5. Huscher CGS, Bretagnol F, Corcione F. Laparoscopic Colorectal Cancer Resection in High-Volume Surgical Centers: Long-Term Outcomes from the LAPCOLON Group Trial. World J Surg. 2015; 39(8): 2045-2051. doi: 10.1007/s00268-015-3050-4.

6. van der Pas MH, Haglind E, Cuesta MA, Fürst A, Lacy AM, Hop WC, et al. Laparoscopic versus open surgery for rectal cancer (COLOR II): short-term outcomes of a randomised, phase 3 trial. Lancet Oncol. 2013; 14(3): 210-218. https://doi.org/10.1016/S1470-2045(13)70016-0.

7. Benz S, Barlag H, Gerken M, Fürst A, Klinkhammer-Schalke M. Laparoscopic surgery in patients with colon cancer: a population-based analysis. Surg Endosc. 2017; 31(6): 2586-2595. doi:10.1007/s00464016-5266-2.

8. Fagard K, Casaer J, Wolthuis A, Flamaing J, Milisen K, Lobelle JP, et al. Postoperative complications in individuals aged 70 and over undergoing elective surgery for colorectal cancer. Colorectal Dis Off J Assoc Coloproctology G B Irel. 2017; 19(9): O329-O338. https://doi. org/10.1111/codi.13821. 
9. Mamidanna R, Burns EM, Bottle A, Aylin P, Stonell C, Hanna GB, et al. Reduced risk of medical morbidity and mortality in patients selected for laparoscopic colorectal resection in England: a population-based study. Arch Surg Chic Ill 1960. 2012; 147(3): 219-227. https://doi.org/10.1001/ archsurg.2011.311.

10. Cummings LC, Delaney CP, Cooper GS. Laparoscopic versus open colectomy for colon cancer in an older population: a cohort study. World J Surg Oncol. 2012; 10: 31. doi:10.1186/1477-7819-10-31.

11. Devoto L, Celentano V, Cohen R, Khan J, Chand M. Colorectal cancer surgery in the very elderly patient: a systematic review of laparoscopic versus open colorectal resection. Int J Colorectal Dis. 2017; 32(9): 1237 1242. doi:10.1007/s00384-017-2848-y.

12. Parker JM, Feldmann TF, Cologne KG. Advances in Laparoscopic Colorectal Surgery. Surg Clin North Am. 2017; 97(3): 547-560. doi:10.1016/j.suc.2017.01.005.
13. Gani F, Cerullo M, Zhang X, Canner JK, Conca-Cheng A, Hartzman AE, et al. Effect of surgeon „experience” with laparoscopy on postoperative outcomes after colorectal surgery. Surgery. 2017; 162(4): 880-890. doi:10.1016/j.surg.2017.06.018.

14. Park IJ, Choi G-S, Lim KH, Kang BM, Jun SH. Multidimensional analysis of the learning curve for laparoscopic resection in rectal cancer. J Gastrointest Surg Off J Soc Surg Aliment Tract. 2009; 13(2): 275-281. doi:10.1007/s00464-014-3569-8.

15. Meagher AP, Yang S, Li S. Is it right to ignore learning-curve patients? Laparoscopic colorectal trials. ANZ J Surg. 2017; 87(11): 898-902. doi:10.1111/ans.14070.

16. Gietelink L, Wouters MWJM, Bemelman WA, Dekker JW, Tollenaar RA, Tanis PJ. Reduced 30-Day Mortality After Laparoscopic Colorectal Cancer Surgery: A Population Based Study From the Dutch Surgical Colorectal Audit (DSCA). Ann Surg. 2016; 264(1): 135-140. doi:10.1097/ SLA.0000000000001412.

\title{
Zabiegi laparoskopowe w leczeniu chorych na raka jelita grubego - ocena po wprowadzeniu techniki w ośrodku onkologicznym
}

\begin{abstract}
I Streszczenie
Wprowadzenie i cel pracy. W województwie świętokrzyskim rak jelita grubego jest trzecim najczęściej występującym nowotworem złośliwym u mężczyzn i drugim u kobiet. W 2015 roku odnotowano 354 nowych zachorowań u mężczyzn i 290 u kobiet. Zabiegi minimalnie inwazyjne wraz z nowoczesnym podejściem do opieki okołooperacyjnej stały się nowym wyzwaniem dla chirurga i łącznikiem do chirurgii robotowej. Celem pracy jest analiza powikłań chirurgicznych w pierwszych latach od wprowadzenia technik laparoskopowych do operacji nowotworów jelita grubego.

Materiał i metody. W 2011 roku rozpoczęto w Klinice Chirurgii Onkologicznej Świętokrzyskiego Centrum Onkologii laparoskopowe resekcje jelita grubego. Metodą tą leczono 196 chorych, głównie pacjentów z rakiem okrężnicy lub odbytnicy. U 30,6\% chorych wykonano konwersję do zabiegu metodą otwartą. Przeanalizowano powikłania oraz wyniki odległe, oceniając czas zabiegu, długość pobytu pacjentów w szpitalu, powikłania miejscowe, śmiertelność wczesną i późną.

Wyniki. Czas zabiegów laparoskopowych był dłuższy w porównaniu do zabiegów przez laparotomię. Mediana pobytu pacjenta w szpitalu wyniosła $7 \mathrm{dni}$. Odnotowano następujące powikłania: zakażenia miejsca operowanego u 4,1\% chorych, krwawienie, ewenteracjęl lub przepuklinę oraz nieszczelność zespolenia u 2,4\% pacjentów. Konwersję wykonano u 58 chorych, najczęściej z powodu zrostów (42\%) lub rozległego nacieku nowotworowego (39\%). Wczesną śmiertelność pooperacyjną do 30 dni od zabiegu odnotowano u 0,5\% pacjentów, natomiast do roku po zabiegu u $8,2 \%$ chorych.

Wnioski. W trakcie laparoskopowych resekcji jelita grubego nie zaobserwowano zwiększonej liczby powikłań okołooperacyjnych. Zabiegi laparoskopowe są bezpieczną metodą leczenia, szczególnie w grupie starszych chorych. Duży odsetek konwersji świadczy o potrzebie doskonalenia umiejętności operującego zespołu.
\end{abstract}

\section{Słowa kluczowe}

chirurgia laparoskopowa, laparoskopia, rak jelita grubego, powikłania 